\title{
Teachers' Perception of Transition Preparedness by Learners with Physical Disabilities Towards Employment: Joytown, Joyland and Mombsasa Special Secondary Schools, Kenya
}

\author{
Lucy Muthoni Marete $^{1} \quad$ Dr. Otube Nelly ${ }^{2}$ Dr. Murugami Margaret ${ }^{3}$ \\ Kenyatta University, Department of Special Needs Education, P.O BOX 43844-00100, Nairobi, Kenya
}

\begin{abstract}
The study sought to find out teachers' competency of transition preparedness by learners with physical disabilities (PD) towards employment: Joytown, Joyland and Mombasa Special Secondary Schools in Kenya. The descriptive survey research design was used to find out teachers competency of learners preparedness towards employment. The study adopted both qualitative and quantitative research approaches where mixed method design was used to collect and analyze the data. The study was carried out in Joytown in Thika West, Kiambu County, Mombasa Secondary in Mombasa County and Joyland in Kisumu County. Purposive sampling was used to select the three physically handicapped Special Secondary Schools, which were the earliest to be established by missionaries in Kenya. The piloting of the instruments was conducted in Joytown special school to form three learners and all teachers teaching form one and form three who were not included in the main study. Interview schedule was administered to administrators while the teachers and learners with physical disabilities filled the questionnaires. Self-efficacy theory was used to interpret dynamics specifically for teachers and learners with physical disabilities in the classroom. Statistical Package for Social Sciences (SPSS) was used to analyze quantitative data while Computer Assisted Qualitative Data Analysis System (CAQDAS) was used to analyze interview schedules. The importance of this study was to create awareness of preparedness by teachers to enable learners with physical disabilities to transit to employment enhanced by teachers' teaching strategies, availability of resources and knowledge of pre-vocational activities that enhanced their perception towards learners with physical disabilities. After the findings, the researcher recommended that Kenya Institute of Curriculum Development (KICD) should develop curriculum contents, which will suit the needs of learners with special needs including those with physical disabilities. The findings may enhance appropriate pre-vocational skills for learners with physical disabilities because it has a futuristic relevance, widens the scope of individual economic activities, and reduces the burden of dependency on others. Further, it hopes to provide educational planners and policy-makers with a framework on which policies can improve the quality of teaching special needs education hence facilitate transition preparedness to employment for learners with physical
\end{abstract}

Keywords: Academic Qualification, Competency, Physical disabilities, Transition preparedness, Teachers professional Knowledge

DOI: $10.7176 / \mathrm{JEP} / 11-18-24$

Publication date:June 30th 2020

\section{Introduction}

Nearly 6.5 million learners with disabilities, be they of a physical nature or otherwise, are being served by teachers trained in special education who may be unprepared to use transitional competency, such as skills to train learners in pre-vocational activities, to facilitate transitional planning that may lead to sustainable postsecondary success specifically (National Centre for Education Statistics, 2010). Due to factors such as illpreparedness and perception of teachers, many learners are leaving secondary schools without accessing competitive employment, functional independence or dependable prospects for social engagements. Persons with physical disabilities often use assistive devices such as crutches, canes, wheelchairs and artificial limbs for mobility. In an educational setting, these learners have to make use of their gross and fine motors to enhance their day-to-day activities such as toileting, writing, grooming or dressing. Those with severe physical disabilities or secondary disabilities such as cognitive and speech difficulties, or cannot perform any activities on their own, have difficulties in accessing education, healthcare employment or rehabilitation services (African Union of the Blind, 2007).

\section{Classification of Learners with Physical Disabilities}

Learners with physical disabilities maybe classified into three categories Federal Individual with Disabilities Education Act (IDEA) they include orthopedic impairment include genetic abnormality, diseases such as poliomyelitis, bone tuberculosis, injury birth trauma, amputation, burns and fractures among others. Learners with other health impairments (OHI) have limited strength vitality or alertness, including heightened alertness to environmental stimuli, which result in limited alertness with respect to the educational needs. OHI can be due to chronic or acute health problems such as asthma, attention deficit disorder or attention deficit hyperactivity 
disorder, diabetes, epilepsy, a heart condition, hemophilia, lead poisoning, leukemia, nephritis, rheumatic fever, sickle cell anemia and Tourette syndrome. Such conditions adversely affect the child's educational performance and therefore require services, which can include designed instruction and a wide-ranging support to address the learner's needs that result from his/her disabilities.

Persons with physical disabilities suffer physical, social, and psychological barriers and commonly denied the opportunities to participate in social and community life, largely due to negative perceptions, attitudes, and discrimination from people without disabilities (Barners \& Mercer, 2010). The youth stage of human growth and development has been conceptualized as a transitional phase from childhood to adulthood. Key events, stages, or rites of passages mark it. These include activities such as the transition from school to work, leaving from home to independent living, and from dependence within the parental family to finding a partner, becoming and being independent (Punch, 2002, Evans, 2008 Worth, 2009). It has been considered a critical socioeconomic life-changing period during which young people acquire and develop valuable skills in education and training, which are essential for other transition pathways and a crucial component of achieving (Roberts, 2003, World Bank, 2013). Phrases such as "empowerment" "equal right" and "self-determination" are very appropriate in handling issues of education and employment for learners with physical disabilities.

\section{Transition Preparedness and Competency}

"Transition is an ongoing process of planning, implementing, evaluating and balancing the details of parents' lives vis-à-vis those of children in the quest to achieve an integrated quality of life for the entire family". Transitional planning includes pre-vocational training, replacement of any limbs with artificial ones, mobility training, physical therapy, and occupational therapy. (Ankeny, Wilkins \& Spain, 2009: 28). Perhaps the most dependable persons in the transition process are special education teachers, for it is their responsibility to coordinate the transition plan, guiding the learners and the outside agencies as they work in concert towards attaining the transition goals as planned. The position of a special education teacher is a difficult one they face many challenges as they work to implement learner's transition plans using available and sometimes, scarce resources and a restricted curriculum used for all learners in school. As a result, transition outcome of learners with physical disabilities is influenced by negative self-perception of special education teachers' capacity to plan and deliver transition services effectively. The majority of these learners with physical disabilities experience hardships because of widespread socio-cultural and economic prejudices, stigmatization and frequent abuse and violence, both of a physical or psychological nature.

\subsection{Review of other Studies on Teachers' Competency and Profession}

A study carried out in the United States by Curry and Jones (2014), on implementing transitional activities, showed that some trained teachers lamented that their personnel training programs did not deal with specific knowledge and skills essential to teaching such as overseeing paraprofessionals, making use of professional literature to address and teaming up with general education teachers. Carton, Brauner, Klein Scroll and Willing, (2002) also, conducted a study in the same country and revealed that teachers' perception had an impact in that it was instrumental in identifying best instructions practices and in bringing about changes in areas such as preparation and professional development programs. Lubbers, Repetto and Mcarray, (2008) however, posits that special education teachers who were not equipped to plan and deliver transitional services or were not confident in their capability to plan and deliver transitional services may perhaps contribute to the unfortunate outcome that learners with physical disabilities might demonstrate after school. As a result, these teachers reported that they did not feel highly qualified to work with learners with disabilities for this reason; special education teacher's perception of their capacity to plan and deliver transitional services may have a negative impact on the transitional outcome o teaching learners with physical disabilities to teaching.

A research done by Heller, Dykes, Best and Cohen (1999) in the United States of America found that a large proportion (40\%) of special education teachers certified to teach learners with physical disabilities do not feel prepared. They lack essential knowledge and skills in about half of the competencies needed to educate learners with physical disabilities. Further, the government of the USA required that teachers who teach learners with physical disabilities possess specific knowledge and skills. They must be well versed in a range of instructional strategies, physical management, health maintenance, environmental adaptations and assistive technology. They need to be able and willing to collaborate with a variety of personnel; must be ready to modify curricula to accommodate the individual characteristics of these learners, apply knowledge of disability conditions to educational outcomes which will enhance employability of these learners with PD (Best, Heller \& Bigge; 2005. Council of Exceptional Children, 2003).

In Ireland a study done by Farral and O’Neil (2011) interviewed learning support teachers in Irish mainstream secondary schools and they established that all of the participants expressed concerns regarding the ability of subject teachers who cater for the needs of learners with special needs education in terms of the differentiation of materials, learning resources and contact hours. They noted that there was need for mandatory 
training for all teachers to improve competency levels when dealing with learners with disabilities. Winter, (2006) carried out a researcher in Northern Ireland amongst 203 trainee teachers with regard to the effectiveness of their professional training in preparing learners with special needs in an inclusive classroom setting. Results of the study showed that 89 per cent of the teachers' responses did not feel that their professional training had adequately prepared them to teach learners with any type of disability in an inclusive, be it of physical, cognitive, emotion or hearing impairment.

Many studies including one done in Saudi Arabia emphasized that Special Needs Education should move from focus on a correct educational procedure to promoting meaningful outcomes. Accomplishing these meaningful outcome have become the focus and intent of transition services, which include among other things independent living, active community participation and employment. The bridge between life in school and living with a family to become totally independent and adjusting to a demanding life is through transition services. Webb, Patterson, Syrerud \& Seabrooks-Blackmor (2008) outlined areas that should be covered in transition to post-secondary education programs in order to fulfill students needs to include self-determination, social skills, academic preparation, accommodation and assistive technology. Almuaqel (2008) suggests that education teacher in Saudi Arabia are generally prepared to work in elementary schools with students of young ages, which would make work related transition services a new aspect for them. In addition, it is important to remember that in Saudi Arabia, there is no cumulative experience with transition process to assist students in making the move from school to work environment. Without experience, one cannot expect teachers to have a major effect on transition unless they receive help from specialist agencies or relevant professionals.

In Botswana the teaching of learners with disabilities especially in an inclusive classroom has not been found successful largely due to the shortage of specialized educators and lack of teachers' preparation colleges. (Chitiyo \& Chitiyo, 2007). One issue that Botswana is still grappling with is making curricula accessible to all children, with and without disabilities. The majority of teachers are not trained in special needs education to meet learners needs Consequently, they are unable to tailor the curriculum to meet the diverse needs of children in a general education setting (Abosi, Chitiyo \& Chitiyo; Matale, 2000). School facilities, resources, buildings and the teacher's qualification influence young people's educational experience and personal development. Children with disabilities and young people generally face greater difficulties in attending and completing school and have lower levels of education than non- disabled peers (Filmer, 2008).

According to Charlotte (2014) who carried out a study in Peninsula Malaysia noted that the students in learning institutions are influenced by quality of teaching, yet most schools still cannot explain what constitutes good teaching. In the absence of a clear definition of teaching shortcomings, problems will arise because teachers do not know what is expected of them and how to improve their practices in the classroom and this can harm the results of learners' achievements. This study also identified five domains in teachers' competencies namely: preparation, classroom environment, communication during teaching and professional development of a teacher.

A study by Otube (2011) reiterated that physical therapies were quite helpful, in training learners with physical disabilities particularly ataxic cerebral palsy to learn better ways in mobility. A teacher trained in general methodology may not achieve this since it requires a lot of technical professional preparedness. Going by the research of Otube (2011) there were around 250,000 teachers population in Kenya, with only 5\% of total population of teachers trained on special needs education, equating to only 12,500 teachers. Only $8 \%$ of these special needs teachers have specialized in areas of physical handicap including cerebral palsy, that represents 1000 of the total population. Contrast this with the Ministry of Education (2009) recommended ratio of teacher to pupil 1:10 so that they can cater for these learners with special education needs adequately and effectively. Special education teachers need to be better prepared in realms of technical expertise and pedagogical knowledge and other important forms of knowledge, which will prepare them as true advocates of special needs education. A report by the Kenya National Survey of Persons with Disability (National Coordinating Agency on Population and Development, 2008) noted that about 30\% of all individuals with disabilities in the country have physical disabilities and they need to secure employment equally like people without disabilities. The need for highly qualified teachers in our schools is not negotiable. Therefore, the Ministry of education, institutions of higher learning and schools around the country are struggling to set criteria that designate educators as highly qualified. There are many learning institutions and colleges, which offer special needs education to teachers and at the same time, trained in planning and delivering transitional services. Blarchett et al., 2005, Wehmeyer (2003) and Morningstar and Clark (2003) found that special education teachers need to have basic transitional competency and knowledge that goes beyond the abilities and knowledge many secondary school special education professionals acquired in their undergraduate studies. Questions linger as to whether lack of selfefficacy and competence for teachers in the area of transition planning and implementation inhibits ability to adequately plan and deliver transition services.

The disparate perception of teachers' preparedness to manage the learning of learners with physical disabilities compared with perception of preparedness to prefer such instructions have implication on how 
special education develop expertise. Leko, Brownell, Sindelar \& Murphy (2000) noted that a mark of expertise in special education is a well-integrated knowledge base, which may take up to ten years. Preparing learners with special needs education for the workforce is an important role for schools administrators and teachers to help learners with disabilities for the world of work in a number of ways. Teachers should have working knowledge of the career development and the general career objectives that exist in transition preparedness.

Educational strategies and skills that are widely considered prerequisites to gaining access to employment need to be designed by policy makers to be results-orientated processes that focus on improving the academic and functional achievement of learners with physical disabilities (Lloyd 2005, ILO 2010). International and European Institutions such as UNESCO, the ILO and the European Commission recognize that basic education should lead to employment after school for all learners with or without disabilities. Individual Disability Education Act (IDEA, 2004) enacted in Kenya has long required schools to help learners design "transition plans" and provide job training for their lives after graduation. Amendment of IDEA was not only to allow learners with disabilities to access free and appropriate education (FAPE), but also to prepare them for employment and independent living. This preparedness is termed transition preparedness which involves the delivery of activities that would permit the learner to engage in services at other educational levels and for real world living.

A National Survey on children with disabilities and special needs education conducted in Kenya between 2016 and 2017 revealed that children with physical disabilities comprise three percent of country's total population out of this a significant number is enrolled in schools however, the rate of school drop-out remains high due to lack of support services in most of learning institutions. The Kenya Institute of Special Education, in conjunction with the Ministry of Education, established that the education system in Kenya is ill equipped to support learners with special needs. Further, they revealed glaring inadequacy of teacher trained to handle special education learners. In addition, it is this inadequacy, which prompted researcher's concern to examine teachers' perception on transition preparedness of learners with physical disabilities, towards employment in the three selected special secondary schools for learners with physical disabilities in Kenya.

\section{Theoretical Framework}

The study was guided by concept of self-efficacy theory that is associated with the social learning theories that Albert Bandura developed. This concept deals with goals, values, actions, professional functioning and loyalty of the persons who can perform a certain tasks (Bandura 1986, Pinquart, Juang \& Silberesian,2003). The broad idea of self-efficacy is premised on interactions with the environment and helping the individual to cope and realize his/her skills effectively through mere observation (Bandura, 1997, Knoll, Rieckmann \& Schwarzer, 2005).

In this study self-efficacy theory is premised on perceived teachers beliefs about their capabilities to produce designated levels of performance that exercise influence over events that affect the lives of learners with physical disabilities. It concerns itself with how people feel, think, motivate themselves and behave. Such beliefs produce diverse effects through four major processes, namely cognitive, motivational, affective and selection processes. Teachers' beliefs about their self-efficacy on transition preparedness to employment for learners with physical disabilities can be developed through four main sources of influence, namely, mastery, experiences, success levels and robust beliefs in one's personal efficacy.

Teacher's self-efficacy has been known to improve during teacher training (Holy \& Spero, 2005). The school years are a crucial time in modeling a child's life. Schools function as primary areas for the cultivation of social and cognitive competencies. Sources of efficacy in the school include formal instruction, instructor's interpretation of successes and failures, peer modeling and personal comparisons with peers. A school is a place where learners develop the cognitive competencies and acquire the knowledge and problem-solving skills essential for facing life challenges in the larger society. Here their knowledge and thinking skills continually get tested, evaluated and socially compared. As learner master cognitive skills, they develop a growing sense of the intellectual efficacy. The task of creating learning environment conducive to development of cognitive skills rests heavily on the talents and self-efficacy of teachers. Those who have a high sense of self-efficacy about their teaching capabilities can motivate their learner and enhance their cognitive development more effectively (Holy \& Spero, 2005)

Influence from peers either uplift or depress learner's feelings of confidence and judgment of personal capabilities, encouragement from parents, teachers and peers whom learners trust boost their confidence. Emotional reactions can heighten or diminish confidence; feelings of stress, tension and depressed mood have physical and psychological effects that negatively affect performance (Bandura 1997, Schunk \& Pajares, 2009). Bandura (1997) posited that there are several ways to increase self-efficacy: such as by successful experience in execution of challenging tasks, study of models of behavior, verbal persuasion and high level of mental and physical alertness.

Bandura (1990) also tackles the beliefs in the capacity mobilization, motivation, cognitive resources and 
actions, which are required for control of the demands of the tasks. Teachers' feelings of preparedness may influence their ability to perform teaching tasks. Gilbson \& Dembo (1984) tabled self- efficacy in the context of educational work and classified the feelings of self-efficacy of teachers' dimensions as "general self-efficacy of teachers into beliefs that generate changes". The second dimension is "personal self-efficacy of the teacher" which a teacher himself is capable of generating to bring change in the studies. A level of self-efficacy helps the teacher to organize the knowledge and abilities at his disposal, in order to implement the methods of action required in filling the accepted tasks of teaching and to achieve future goals. The main task for the teacher here is to advance the achievement of learners particularly those who can be considered as problematic or lacking motivation.

The self-efficacy theory assumes that if special education teachers believe that they can make a difference in the lives of learners with physical disabilities they will plan and implement transition services in ways that demonstrate those beliefs. The teachers' beliefs about capability are a strong predicator of teachers' effectiveness. Those with stronger self-efficacy beliefs tend to improve learners transition outcome more. The idea that special education learners should think about life after school became nascent in the 1960's when-work study programs and concept of normalization began to take shapes (Ecks \& Ochoa, 2005; Luppers et al., 2008; Myklebust \& Baterick, 2005).

In conclusion, teachers' competency is influenced by multiple factors such as the amount of effort invested in classroom activities and learning resources, environmental factors, the use of goal setting especially short and long-term objectives. Further, learners career aspiration, use of planning and organization, exposure to new ideas, persistence in the face of confidence they have in the abilities to learn new skills which improve future performance (Ischanner-Moran \& Hoy, 2007).

\section{Research Design}

This study adopted descriptive survey research design to allow the researcher to gather information, summarize, present and interpret the purpose for clarification (Orodho, 2008). This design was relevant for the current study as it sought to understand teachers' perception of transition preparedness by learners with physical disabilities towards employment. A mixed method research methodology that entails collecting, analyzing and "mixing" both qualitative and quantitative in a single study was used to help the researcher to understand research methods (Creswell, 2008). In this design, qualitative and quantitative approaches were used to confirm, cross-validate or corroborate findings within a single study. Using a combination of qualitative and quantitative data collection can improve an evaluation by ensuring that the limitation of one approach of data collection and analysis was strengthened by the other approaches (Green, 2001). In quantitative approach the data was expressed in numbers where statistical tests was used to make statements of descriptive and inferential statistics using standard deviation, mean and multiple regression correlation to get the results. The data from qualitative approach helped to identify the characteristics of learners with physical disabilities, teachers and administrators, hence presented thematically.

\section{Target Population}

This study, the researcher targeted 540 teachers, 30 administrators and 830 learners from the three selected secondary schools for learners with physical disabilities namely; Joytown, Mombasa and Joyland in Kenya. The total population was 1400 from which sample size was drawn.

\begin{tabular}{|l|l|l|l|l|l|}
\hline \multirow{2}{*}{ Categories } & \multicolumn{2}{|l|}{ Target population } & Total & \multirow{2}{*}{ Percentage \% } \\
\cline { 2 - 5 } & $\begin{array}{l}\text { Mombasa sec. school } \\
\text { for physically } \\
\text { handicapped }\end{array}$ & $\begin{array}{l}\text { Joytown Sec. school } \\
\text { for physically } \\
\text { handicapped }\end{array}$ & $\begin{array}{l}\text { Joyland Sec. school } \\
\text { for physically } \\
\text { handicapped }\end{array}$ & & \\
\hline Administrators & 10 & 10 & 10 & 30 & $3 \%$ \\
\hline Teachers & 200 & 110 & 230 & 540 & $54 \%$ \\
\hline Learners & 310 & 220 & 300 & 830 & $83 \%$ \\
\hline Total & 520 & 340 & 540 & 1400 & 140 \\
\hline
\end{tabular}

\section{Sampling Technique}

The researcher used purposive sampling to select the special secondary schools because they have highest population of learners with physical disabilities in Kenya. This type of sampling refers to the process by which a researcher selects a sample basing on the experience or knowledge of the group sampled. The teachers were selected because they teach in these schools and had relevant information for this study. The schools have one administrator therefore each was chosen since they had information about teachers' competency, curriculum used by teachers, policies and regulations regarding learners with physical disabilities and challenges facing the learners and the school as a whole.

According to Mugenda and Mugenda (2003), when the study population is less than 10000, a sample size 
between 10 and $30 \%$ is a good representation of the target population and hence $10 \%$ is adequate for analysis. Therefore, teachers (540x0.1) administrators (30x0.1) learners (830x0.1) were considered for making a appropriate population of 140 .

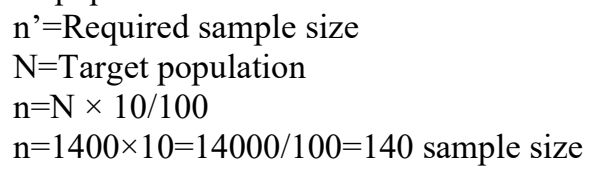

8. Target and sample population

\begin{tabular}{|l|l|l|l|l|l|l|l|}
\hline Subject & \multicolumn{2}{l}{$\begin{array}{l}\text { Mombasa Special Sec. } \\
\text { School for PH }\end{array}$} & $\begin{array}{l}\text { Joytown Special Sec. } \\
\text { School for PH }\end{array}$ & $\begin{array}{l}\text { Joyland Special Sec. } \\
\text { School for PH }\end{array}$ & $\begin{array}{l}\text { Total } \\
\text { Sample } \\
\text { pop. }\end{array}$ \\
\hline & Target & Sample & Target & Sample & Target & Sample & \\
\hline Administrators & 10 & 1 & 10 & 1 & 10 & 1 & 3 \\
\hline Teachers & 200 & 20 & 110 & 11 & 230 & 23 & 54 \\
\hline Learners & 310 & 31 & 220 & 22 & 300 & 30 & 83 \\
\hline Total & 520 & 52 & 340 & 34 & 540 & 54 & 140 \\
\hline
\end{tabular}

\section{Research Instruments}

The objectives of the study formed the basis from which the research instruments were constructed. In data collection, the teachers and learners with physical disabilities were given questionnaires to complete by the researcher. An interview schedule with semi-structured questions were given to the administrators because they were the key informants to this study and had in-depth knowledge about the school administration, policies and regulations, pre-vocation activities carried in the school, challenges and teaching of learners with physical disabilities. The combination of mixed methods of collecting data was to avoid response and information bias to ensure validity, reliability and accuracy of information gathered

\section{Data Analysis}

The following steps were taken to analyze the data to provide a more comprehensive analysis of different types of interrelated social process. The researcher checked the completed questionnaires and interview schedules to ascertain their accuracy and uniformity to responses. Field notes from interview schedule were edited, coded and organized to emerging themes. A management software computer program such as Assisted Qualitative Data Analysis System (CAQDAS) was used to code, manage and analyze data, further it explored the relationship between the coded in one file and theoretical explanations. This software was to identify description of how and when each theme would occur and any qualification or exclusion of emerging themes either positive or negative eliminated possible confusion.

The result produced the report in a qualitative data presented in a narrative form. Questionnaires were analyzed using Statistical Package for Social Sciences (SPSS) involving such processes as coding, categorizing and making the essential meanings of the phenomenon. Data were converted into percentages and presented in tables of frequency distribution, Charts and Correlation analyses were conducted to determine the relationship among each of variables measured. The analysis procedures included descriptive and inferential statistics frequency competency rating related to the scales of preparation to perform the activity. These statistics indicated the frequency means and standard deviations for the demographic variables.

\section{Results and Discussion \\ 4.1Demographic data}

Demographic data was discussed under the following sub-title: gender of the respondents both teachers and learners with physical disabilities and number of years teachers have taught in the three selected secondary schools. 
4.2 Demographic Information of the Study Population

Table 4.1: Learners with PD, teachers' and administrators demographic information

\begin{tabular}{llll}
\hline Respondents & Demographic information & Number of respondents & Percent \\
\hline Learners $(\mathrm{N}=83)$ & Gender & 60 & 72.3 \\
& Male & 23 & 27.7 \\
\hline Teachers $(\mathrm{N}=54)$ & Female & 30 & 55.5 \\
& Male & 24 & 44.4 \\
\hline \multirow{2}{*}{ Administrators $(\mathrm{N}=3)$} & Female & 2 & 66.7 \\
& Male & 1 & 33.3 \\
& Female & & 14.8 \\
& Years taught in the school & 8 & 29.6 \\
& Less than 5 year & 16 & 24.1 \\
& $6-10$ years & 13 & 31.5 \\
\hline
\end{tabular}

\section{Source: Research Data: 2016}

Table 4:1 indicates the demographic information of respondents, which included the administrators' gender, teachers' gender, the learners' gender, and the teachers' years of teaching experience. This helped to determine if gender and years of teaching influenced perception of teachers' transition preparedness by learners with physical disabilities towards employment. More than half of male teachers participated in this study while the rest were female. The teachers who participated in this study had taught in their current schools between less than a year and more than 25 years. Thirty-one of the teachers had served for more than 25 years; twenty four percent had taught between $11-20$ years, twenty nine percent had taught between $6-10$ years while fourteen per cent had only taught for less than one year. Learners with physical disabilities in these schools comprised seventy-two per cent males whereas female learners accounted for twenty eight per cent. A report on gender analysis on disability in schools (Midred, 2002) noted that disability limited educational opportunities more significantly for women than men, thus their enrolment and retention rates remain low. This tally with the researcher finding of female enrollment in the selected schools under study that is far below compared with male.

\section{Teachers' Qualifications and Skills}

The second objective was to establish teachers' competency of transition preparedness by learners with physical disabilities towards employment. The three selected secondary schools had enough teachers however; the researcher thought that it was important to gauge the competency of the teachers by probing their academic qualification and areas of specialization in special needs education.

Figure 4.5 Trained and untrained teachers in the area of Special Needs Education (Physical handicap)

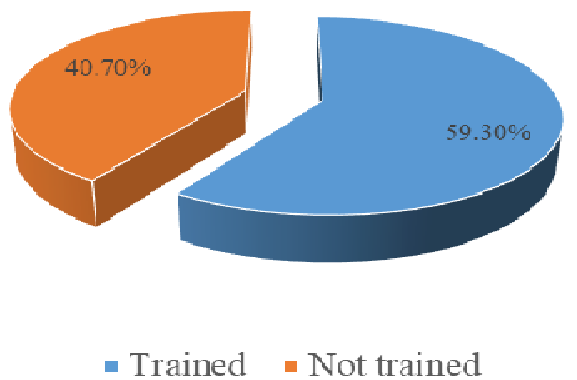

\section{Source: Research Data: 2016}

It was important for the researcher to establish if teachers' are trained in the area of special needs education, which enhances their competence. Figure 4.5 shows the percent of teachers, trained in the area of Special Needs Education. Majority more than half of teachers sampled had a degree in education and the same time trained in special needs education in the area of physical disability and competently was teaching learners with physical disability competently. They were competent in that they could adapt relevant methods of teaching to suit the needs of these learners. Forty-one percent of the teachers did not have specialized training in the area of physical disabilities. This indicated that the minority of the teachers though trained in education had no skills and knowledge to handle learners with PD. A research done by Heller, Dykes, Best and Cohen (1999) in the United States of America found that a large proportion (40\%) of special education teachers certified to teach learners with physical disabilities do not feel prepared. They lacked essential knowledge and skills in about half of the competencies needed to educate learners with physical disabilities. The government of the USA advocated that 
teachers who teach learners with physical disabilities must possess specific knowledge and skills. They must be well versed in a range of instructional strategies, physical management, health maintenance environmental adaptations and assistive technology. A study by Lee et al. (2011) in USA noted teachers trained in special education sometimes did not competently address the needs of learners with physical disabilities. The constraints being lack of collegial support and understanding, inadequate resources, insufficient training, the need to shift the focus from exclusively academics and overwhelming workloads continue to jeopardize the scope of planning that led to valuable transition experiences to acquire employment. Poor perception of transition can cause even the most determined teachers to devalue transition strategies and undermine practices when planning for postsecondary choices including employment. Further, it indicated that training of the teachers in the area of special needs education was vital because they acquire knowledge, skills appropriate to deal with the learners with physical disabilities, and perception towards them would be positive hence promoting their initiative to prepare them adequately to transit to the arena of employment.

Figure 4.6: Teachers academic qualification

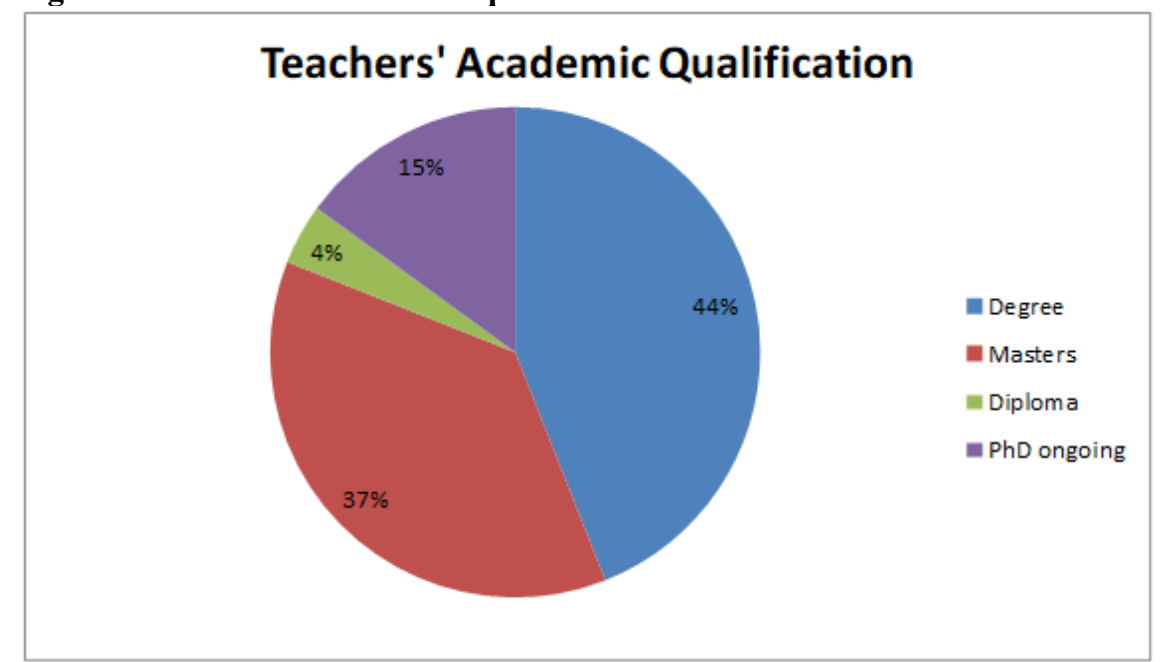

\section{Source: Research Data: 2016}

The researcher further looked into the teachers' academic qualifications to establish whether their academic qualifications affected their perception hence competency in transition preparedness of learners with physical disabilities towards employment. Figure 4.6 clearly indicate the qualifications of the teachers and majority of teachers had degrees, thirty-seven per cent had Masters and fifteen percent were ongoing PhD students. The teachers who had degrees, masters and ongoing $\mathrm{PhD}$ students had a lot of knowledge about learners with physical disabilities hence could handle them efficiently. This indicated that teachers in these schools were academically qualified as stipulated by Teachers Service Commission that teachers teaching secondary schools should be degree holders and above. The findings are in line with studies done in other parts of the World. For example, a study by Benitez, Morning and Frey (2009) suggested that teachers' competencies as well as teacher qualifications are inherent in transition planning best practices; therefore, teachers' qualification should be among areas addressed in teachers training programs. Secondary school special education teachers should have skills and knowledge to enhance transition competency to ensure that learners with physical disabilities receive quality transition preparedness that enables them to have opportunities that lead to reasonable quality of life. Notably, transition competence of teachers cannot succeed without collaboration with the families of learners with physical disabilities and outside agencies during annual meetings, interpreting transition interest inventories; inviting learners in discussions about transition program and available options within the school, as well as within the community. Dialoguing with local agencies about expectations and requirements; realistic community opportunities encouraging participative decision making; arranging field trips for heightened exposure to career fields and frequently embedding transition activities throughout the curriculum (Benitez, Morning \& Frey, 2005; Moran, 2012, Wehmeyer \& Webb, 2011).

Table 4.7: Teachers' Opinion on teaching learners with Physical Disabilities in Special Schools

\begin{tabular}{lll}
\hline Teachers opinion & Number of teachers $(\mathbf{N}=\mathbf{5 4})$ & Percent \\
\hline Always enjoy & 14 & 26 \\
Sometimes enjoy & 28 & 51.8 \\
Not at all & 10 & 18.5 \\
Not sure & 2 & 3.7 \\
\hline Total & $\mathbf{5 4}$ & $\mathbf{1 0 0 \%}$
\end{tabular}

Source: Research Data: 2016 
Based on objective two the competency of teachers was sought in conformity with their opinion towards transition preparedness by learners with physical disabilities. Table 4.7 shows the response twenty-six percent indicated that they always enjoyed teaching them; fifty-two percent sometimes, nineteen percent and four percent could not really explain how they felt when teaching them. More than half of the teachers reported that sometimes they enjoyed teaching learners with PD could be contributed by inability to handle these learners with physical disabilities especially if they are not trained in special needs education. Findings showed that the teachers under study must be trained in the area of physical disability in special needs education to have knowledge and skills to teach these learners, for those who responded that they don't enjoy are teachers who are not trained in the area of special needs education. The findings concur with studies by Lubbers, Repetto and Mcarray (2008) which, concluded that special education teachers who were not equipped to plan and deliver transitional services or confident in their capability to plan and deliver transitional services may perhaps contribute to the unfortunate outcome that learners with PD may demonstrate after school and they concur with the findings of the researcher.

4.4.2 Methods Used by the Teachers

Table 4.8: Teaching methods

\begin{tabular}{lll}
\hline Method & $\begin{array}{l}\text { Number of teachers } \\
(\mathbf{n = 5 4 )}\end{array}$ & Percent \\
\hline Diagnostic prescriptive approach & 22 & 81.5 \\
Group teaching & 3 & 11.1 \\
Peer teaching & 5 & 18.5 \\
Thematic teaching & 15 & 55.6 \\
Question and answer method & 22 & 81.5 \\
Team teaching & 3 & 11.1 \\
Field trip & 0 & 0.0 \\
Discussion method & 22 & 81.5 \\
Exploratory method & 1 & 3.7 \\
Demonstration & 21 & 77.8 \\
Role play & 4 & 14.8 \\
Task analysis & 19 & 70.4 \\
\hline Total N & $\mathbf{5 4}$ & $\mathbf{1 0 0}$ \\
\hline
\end{tabular}

\section{Source: Research Data: 2016}

Table 4.8 shows the different methods teachers' use in delivering the content to establish competency in line with objective two to enhance learners' transition preparedness towards employment. Table 4.8 shows that in these three schools the teachers adapted different methods of teaching depending on suitability and appropriateness on individual needs of these learners with physical disabilities. The researcher identified the following teaching and learning methods; diagnostic prescriptive approach also known as clinical teaching or test-teach-test approach. It is a method of providing appropriate approach to instruction to an individual learner after carefully assessing his/her educational needs. Group teaching also known as cooperative learning is a method of instruction that get students work in groups, peer teaching involves one or more students teaching other students, thematic teaching is an instructional method of teaching in which emphasis is given on choosing a specific theme for teaching one or many concepts. Question and answer method is one in which teachers focus topic then set a question which a student answers hence reacts and then ask another question, team teaching involves a group of instructors working purposely, regularly and cooperatively to help a group students of any age. Field trip also known as excursion is a journey by a group of students to a place away from normal environment, discussion method is a group of activity involving the teacher and the student to define the problem and seek its solution involves listening, thinking as well as the speaking ability of the student. Exploratory teaching method encourages learners to examine and investigate new materials with the purpose of discovering relationship between existing background knowledge and unfamiliar content and concepts. Demonstration method is used to communicate ideas with the aid of visuals such as flip charts. posters and power point etcetera .Role play is a technique that allows students to explore realistic situations by interacting with other people in a managed way in order to develop experience and trial strategies in a supported environment. Task analysis is teaching method in which a teacher breaks down a skill into smaller and more manageable components.

Table 4.8 shows different methods and how often teachers used them to deliver content to learners with physical disabilities. Majority of teachers used diagnostic prescriptive approach, question and answer and discussion method as a teaching strategies while seventy-eight per cent used demonstration methods, seventy per cent used task analysis; fifty-six used thematic teaching. Minority three per cent used exploratory method, eleven per cent used group teaching, eleven per cent used team teaching and fifteen per cent used role play and nineteen per cent used peer teaching. None of the teachers used field trip as a method of teaching.. The study noted that a 
well -prepared and committed teacher would not only provide the academic needs of the learners with PD but also cater for their physical, social, and emotional state to enable them to fit in the society after post- secondary education. From the findings, the study found out exploration methods was not at all used by teachers due to the nature of disabilities the learners have and this led to learners without disabilities to be disadvantaged because were treated equally with those with physical disabilities. The teaching methods determined the approach a teacher may take to achieve learning objectives. Turnbull \& Wilcox (2002) emphasized, "Instructional methods are the how to" in the delivery of training. The methods used in any learning situation are primarily dictated by the learning objective determined by the course developers. To achieve good results in learning environment combination of teaching methods are combined to facilitate the learning experience.

\subsubsection{Teachers' Gender Influence on their Teaching Methods Used on Transition Preparedness to Employment}

It was vital for the researcher to identify the influence the gender of the teachers had on teaching methods practiced in these schools. This was to establish the competency of teaching and methods used depending on the gender. This was in conformity with objective two to enhance teachers' competency hence transition preparedness for learners with physical disabilities to employment. Gender influence on methods of teaching was researched using Pearson moment correlation analysis.

4.4.4 Teachers Amount of Contact Time Spent and Methods of Teaching Learners with Physical Disabilities Predicted Employment Preparedness

Table 4.9: Correlation matrix between duration time and teaching methods used by teachers

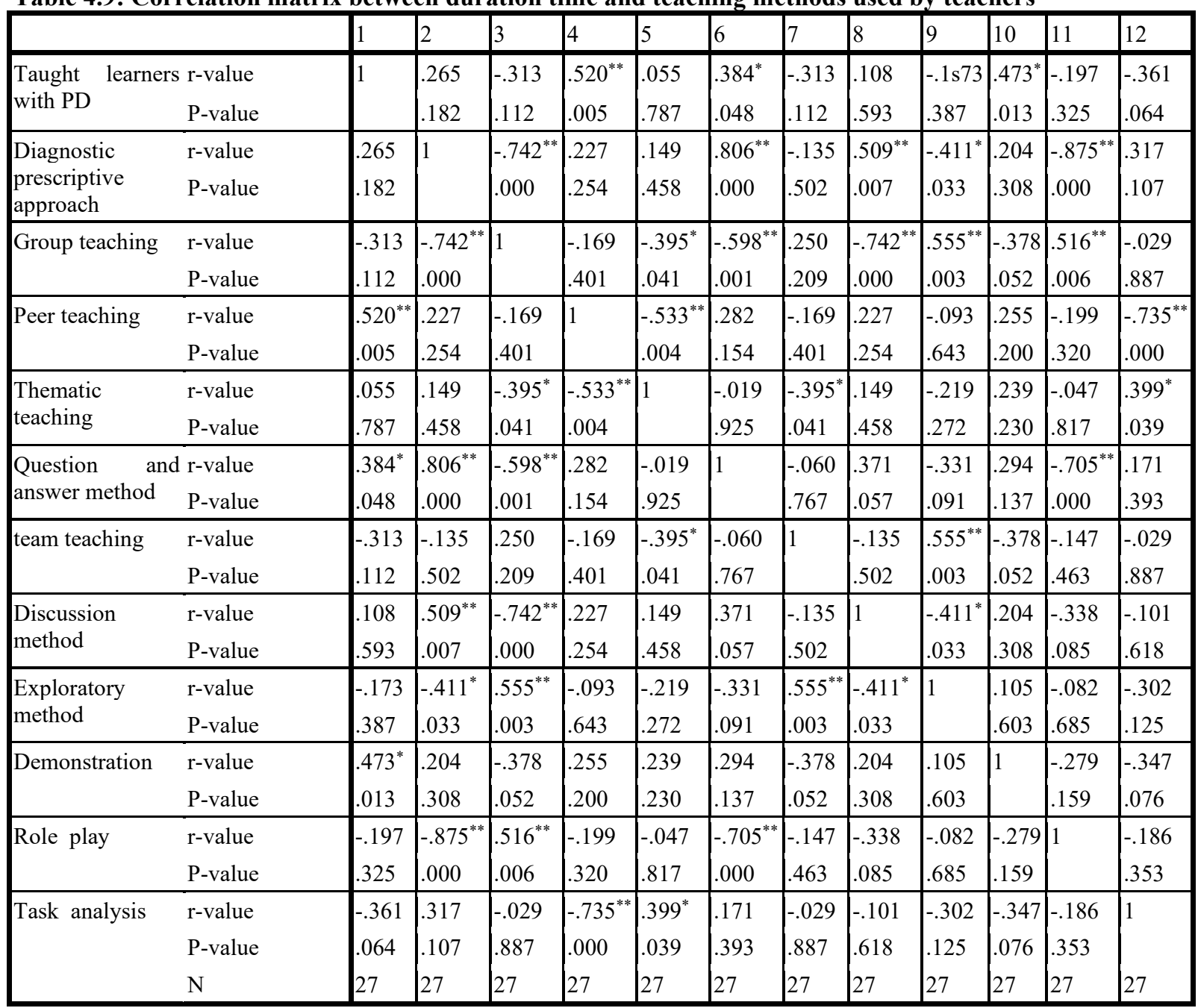

Source: Research Data: 2016

*. Correlation is significant at the 0.05 level (2-tailed).

1- I have taught learners with physical disabilities for, 2- diagnostic prescriptive approach, 3- group teaching, 4peer teaching, 5- thematic teaching, 6- question and answer method, 7- team teaching, 8- discussion method, 9exploratory method, 10- demonstration, 11- role play, 12- task analysis

Table 4.9 was used to demonstrate the relationship between amount of time spent by teacher with the 
learners with physical disabilities and the methods they used to deliver the content. It was important for the researcher to investigate how long the teachers have taught the learners with physical disabilities and the methods they employed in teaching and if it enhanced transition preparedness of these learners towards employment. The findings established that the length of time enhanced teachers' experience hence applying appropriate methods of teaching which contributed to their competent. The study found teachers who have taught for a few years such as less than five years significantly used peer teaching methods $(\mathrm{r}=0.520, \mathrm{P}=$ $0.005)$, demonstration $(\mathrm{r}=0.473, \mathrm{P}=0.013)$ and question and answer method $(\mathrm{r}=0.384, \mathrm{P}=0.048)$. The three methods indicate there was a strong relationship and positive correlation between amount of time spent by teachers and methods used by teachers. The study found out teachers who spent more time with their learners understood them better and were able to prepare them adequately by giving them relevant skills depending on the type of disability they have. This showed that there was significant positive relationship between amount of time, methods of teaching and teachers' perception on transition preparedness for learners with physical disabilities to employment. A study conducted by Williams-Diehm and Lynch (2007) in USA established that learners with physical disabilities felt that their competencies in transition to employment can be enhanced if teachers could improve their teaching strategies. Williams-Diehm and Lynch study concur with researcher's findings in that teaching strategies could be improved if teachers teaching learners with PD can make authentic attempts to guide learners with physical disabilities into careers exposure and opportunities to understand job types.

Further, the findings confirmed what Fullerton, Ruben, McBride and Bert (2011) found in their studies: those special trained teachers emerge with greater versatility and compensatory strategies because of participation in merged teacher's preparation program. Teachers who get more contact time with learners who have physical disabilities ensured that they were exposed to the appropriate pedagogy towards meeting the unique needs of learners with physical disabilities in order to nurture them prior to entering the profession or any employment. The study found that majority of the teachers were of the opinion that the number of years spent teaching learners with physical disabilities enabled them to have positive perception and were able to cope and prepare them depending on severity of their disabilities.

Table 4.10: Teachers' perception on transition preparedness towards employment of learners with physical disabilities were influenced by availability of teaching learning resources

\begin{tabular}{lll}
\hline Influence & Number of teachers $(\mathbf{n}=\mathbf{5 4})$ & Percent \\
\hline Always influenced & 10 & 18.5 \\
Sometimes influenced & 36 & 66.7 \\
Not influenced at all & 8 & 14.8 \\
\hline Total & $\mathbf{5 4}$ & $\mathbf{1 0 0 \%}$ \\
\hline
\end{tabular}

Source: Research Data: 2016

Table 4.10 shows the percent of teachers who were of the opinion that learning resources influenced their perception thereby affecting their competency in teaching was affected. Emphasize on objective two was further sought to establish teachers views on their competency to teach learners with PD. The study showed teachers' competency on preparation of learners with physical disability was influenced by the availability of teaching resources that enhance transition preparedness of learners towards employment. Nineteen per cent stated that their competency was always influenced by the availability of learning materials during pre-vocational activities, majority of teachers stated that they were sometimes influenced by the availability of learning resources, fifteen indicated that they were never influenced by the availability of the teaching resources. This meant their perception towards learners with physical disabilities could not change whether there were learning materials or not.

The results the researcher got from the study confirmed that the learning resources had a lot of effect on teachers' competency and this contributed a lot to their transition preparedness of learners with physical disabilities to employment. A Framework for Action on Special Needs Education (Republic of Kenya, 2009) recommended that appropriate and affordable technology should be used when necessary to enhance success in the school curriculum and to aid communication, mobility and learning therefore, the school should make effort to provide for these learners with physical disabilities.

\section{Conclusion}

Firstly, teachers' pedagogical skills must change to suit the needs of learners with physical disabilities. The researchers found that teachers who hold a degree in Special Needs Education with many years of experience, higher level of academic qualification were more qualified and competent to train and teach learners with physical disabilities towards employment, hence attain positive perception. However, inappropriate preparation of teachers coupled with lack of basic facilities and lack of training in special needs education greatly affected the confidence and willingness of the teachers to work with learners with physical disabilities, which influenced their perception negatively. The study also concluded that due to uniform examination and mode of assessment 
learners with physical disabilities were disadvantaged because the teachers tend to lean heavily in favor of academic results thereby neglecting pre-vocational training. Therefore, Kenya Institute of Curriculum Development to revise curricula for learners with special education needs consider instructional planning that include transition activities, interpretation and dissemination of career assessment and job matching skills to proactively empower learners abilities during transition planning and prepare them to achieve their postsecondary goals such as gainful employment.

\section{Acknowledgment}

I wish to thank all my supervisors for their guidance and contribution to my academic and professional development particularly Dr. Nelly Otube and Dr. Margret Murugami who have been a tireless source of intellectual support and encouragement throughout my study. To the Staff of Special Needs Department I appreciate the ideas we shared together. I am also grateful to the staff of Joytown, Joyland and Mombasa Seconday Schools for availing a friendly environment to carry out research not forgetting the physically handicapped learners, who responded freely to my inquiries, to all, God bless. I further extend my sincere appreciation to Bojana, Mr. Ngugi and Mukiira Mbaya for their expertise and comprehensive editing, not forgetting Mr. Alaro Lawrence for his contribution in Data analysis. Finally but not the least to thank the International Journal of Humanities and Social Studies for accepting to publish my work.

\section{REFERENCE}

African Union of Blind, 2007 (AUB, 2007). State of disabled peoples rights in Kenya (2007). Nairobi, Kenya.

Almuaqel.I.A., 2006). Perceptions of parents' special education teachers and rehabilitation counselor of the individualized transitional plan (ITP) for students with cognitive delay (Unpublished Doctoral University of Idaho Moscow Idaho)

Ankey, E.M., Wilkins, J., \& Spain.J. (2009), July/August. Mothers' Experience of Transition Planning for the children with Disabilities. Teaching Exceptional Children, 41 28-36

Awell, M., \& Cobb, B., (2009) Functional Life Skills Curricular Intervention for Youth with Disabilities a Systematic Review Career Development for Exceptional Individuals 32(21:82-93)

Bandura, A., (1997) Self-efficacy the exercise of self-control. New York Freeman: W.H Freeman and Company

Barners, C., \& Mercer, G., (2010) Exploring Disability Cambrige: Polity Press.Education Teachers'

Benitez, D.T., Morningstar, M.E., \& Frey, B.B., (2009). A Multistate Survey of Special

Bishop, A.G., Brownell,M.T., Klinger, J.K., Leko, M.M.,\& Galman, S.A.C.,(2010). Differences in Beginning Special Education Teachers.The Influence of Personal Attributes, Preparation and School Environment on Classroom Reading Practices. Learning Disability Quarterly, 33(2)75-92

Blanchett, W.J., (2001) Importance of Teachers Competencies as Rated by Special EducatorsTeachers Education and Special Education, 24(1), 3-12 Chitiyo, M., (2006). Special Education in Zimbambwe: Issues and Trends. The journal of the International Association of the Special Education, 7(1)22-27.

Cobb, B., Awell, M (2007). Transition Planning/ Coordinating Intervention for Youth with Disabilities: A Systematic Review,Kalamozoo,MI USA: National Secondary Transition Assistance Center ..

Council for Exceptional Children (CEC). What every special educator should know: The standards for the preparation and licensure of special educators $5^{\text {th }} \mathrm{Ed}$

Creswell, J.W. (2003). Research design qualitative: Quantitative and Mixed Methods approach $2^{\text {nd }}$ Ed. Thousand Oaks, CA: Sages.

Farrel, A.M. \& O’Neil, A,.(2011) Learning Support/ Resource Teachers in Mainstream Post-Primary Schools: Their Perception of the Role in Relation to Subject Teachers; Journal of Special Needs Education in Ireland 25(2), PP. 92-103

Filmer, D.,(2008). Disability, poverty and schooling in developing countries results from 14 household surveys. Government of Kenya (2008). Kenya National Survey on Persons with Disabilities (2007). Government Printer.

Government of Kenya (GoK, 2007a) Ministry of Youth Affairs, Kenya National Youth Policy 2007. Nairobi Government Printer.

Heller, K.W., Fredrick, L.D., Dykes M.K., Best, C.,(1999) A National Perspective of Competencies' for Teachers of Individual with Physical and Health Disabilities. Exceptional Children 65,219-234

Individual with Disabilities Education Improvement Act of 2004 (34 CFR 300.4 320[b] and [c] (20 U.S.C 1414 [d] [1][A][i][VII].(20 U.S.C. $\{1416[a][3][B J]$.

Kenya National of Bureau Statistics Republic of Kenya (2003). Persons with disability Act. Nairobi: Government Press.

Kochhar-Bryant, C., Bassett, D.S., \& Webb, K.W., (2009), Transition to Postsecondary Education.

Lloyd, C. (2005). Growing up global: The changing transitions to adulthood in developing countries, Washington DC. The National Academic press.

Lubbers, J.H, Repetto, J.B \& McGorray, S.P. (2008). Perceptions of Transition Barriers Practices and Solutions 
in Florida. RemediaI and Special Education 29, 280-292.

Michael-Arthur-Kelly(2001) Education and Training in Autism and Developmental Disabilities 2012,47(2) 236252 University of Newcastle.

Ministry of Kenya (2009). The National Special Needs Policy Framework. Nairobi, Retrieved $15^{\text {th }}$ June 2015 S from www.education go.ke

Mitchell, J. M., Adkins, R.H., \& Kemp, B.J. (2006). The effects of aging on employment of people with and without disabilities. Rehabilitation Counseling sBulletin, 49, 3, 157- 165.

Morningstar, M.E.\& Kleinhammer-Tramil, J. (2005). Professional Development for Transition Personnel. Current Issues and Strategies for Success. National Center on Secondary Education and Transition: Information Brief, 4(4).1-6.

Mugenda, O.M., \& Mugenda, A.G., (2003) Research Methods: Quantitative and Qualitative Approaches. Nairobi African Centre for Technology studies

National Center for Education Statistics (2009) The Nation's Report Card: Mathematics 2009 (NCES) 2010-451 Institute of Education Sciences U.S. Department of Education, Washington.D.C

.NCD (National Council on Disability) 2003. People with Disability and Post Secondary Education. Washington Orodho, J.A. (2008). Techniques of Research Proposal and Reports in Education and Social SciencesKANEZJA HP ENTERPRISES. Nairobi.

Otube. N., (2011). Teaching Children Cerebral Palsy. Journal of Special Education 25 (3) 340-351.s

Wehman, P. (2013). Life Beyond the Classroom. Baltimore, MD: Paul.H, Brookes Publishing CO.

Winter, E.(2006) 'Initial Teacher Education: Preparing New Teachers for Inclusive Schools and Classrooms,' Support for Learning, 21(2), PP.85-91

\section{Authors}

First Author- Lucy muthoni Marete Masters' holder Education (Special Needs Education) ongoing Ph.D Student at Kenyatta University waiting to graduate.

Second Author- Dr. Nelly Otube, Lecturer, Kenyatta University- Kenya (Department of Special Needs Education) email: notube 45@gmail.com

Third Author-Dr. Margaret Murugami, Lecturer, Kenyatta University- Kenya(Department of Special Needs Education) email: murugami.margaret@ku.ac.ke

Correspondence Author- Lucy Muthoni Marete, email: marete.lucy@ yahoo.com

Contact Mobile NO. 0721237320 